\title{
Requirements Analysis on Design Assessment of Clothing Practicum Using Expert System
}

\author{
Agus Hery Supadmi Irianti ${ }^{1 *}$, Agus Sunandar ${ }^{2,}$ Ashar Ahmad $S^{3,}$ Asliza Aris ${ }^{4,}$ Titin \\ Irzatul $^{5,}$ Rizki Muhartiningsih ${ }^{6}$
}

\author{
1,2,3,5,6 Department of Industrial Universitas Negeri Malang Malang, Indonesia; \\ ${ }^{4}$ Fashion Department, Faculty of Art \& Design Universiti Teknologi MARA Shah Alam, Malaysia; \\ *Corresponding author. E-mail: agus.hery.ft@um.ac.id
}

\begin{abstract}
Evaluation of the women's clothing practicum, to date, was still conventional. Although there were already pre-determined indicators for assessment on women's clothing practicum, evaluation from the lecturers still contained subjectivity. These occurrences were caused by the fitting step in the evaluation process (the practicum's results were worn by representatives or models). The representative's or models' physical condition such as body shape, appearance, or other factors would influence the lecturers' subjectivity during the evaluation. This research aimed to analyze the requirements on design assessment of women's clothing practicum using exspert. This research used quantitative descriptive method. The population in this research was 60 students from the Fashion Department class 2017. The sampling in this research used the total sampling, while the instruments were closed questionnaires with quantitative descriptive analysis technique. The results showed that the requirements on design assessment of women's clothing practicum using system pakar were: the initial inputs of a skirt, blouse, and gown measurements; whereas the entry data to process the practicum results were the final measurement of clothing, data image from the practice results, and feedback. Keywords: system pakar, practicum assessment, requirements analysis, women's clothing
\end{abstract}

\section{INTRODUCTION}

Practicum assessment is different than other assessments. The practicum of clothes making consists of blouse making, skirt making, and gown making. The practicum assessment has detail indicators and emphasized more on the sewing assessment. The previous research in developing assessment instruments in practicum course according involved: (1) design analysis performance, (2) pattern and pattern drafting performance, (3) pattern placement and material cutting performances, (4) sewing/combining clothing parts performance, (5) finishing performance [1]. The existing research emphasized more on the process of clothes making whereas the study here was to assess the detail of practicum in clothes making. The learning result assessment on fashion using exspert is the development of evaluation model to minimize the subjectivity in evaluating the practicum in clothes making. Generally, exspert is a system that adopts human knowledge to a computer so that the computer could solve a problem like the exspert systems. Exspert helps the exspert system to save their exspert systemise, and this system would work consistently to solve a problem. A good exspert is designed to solve a particular problem by imitating the exspert systems' performances. In the design, exspert combined the inference rule based on knowledge. A combination of both skills is saved in a computer, which next is used in decision making to determine the evaluation result. To understand the exspert, Bayes theorem is used. Bayes theorem has several advantages, such as easy to understand, only required simple coding, and faster in calculation [2]

Bayes theorem is used to calculate the probability of an event based on the influence of the observation. The Bayesian theory is also used as a decision making tool to update the reliability of information.

Bayesian probability theory is a branch of mathematical statistics theory that made it possible for us to make an uncertainty model from an even by combining general knowledge with facts from observation. Bayesian theory, according has several advantages: 1) easy to understand, 2) only need simple coding, 3) faster to calculate.[3] The next figure shows the practicum assessment flow chart using exspert [4]. 


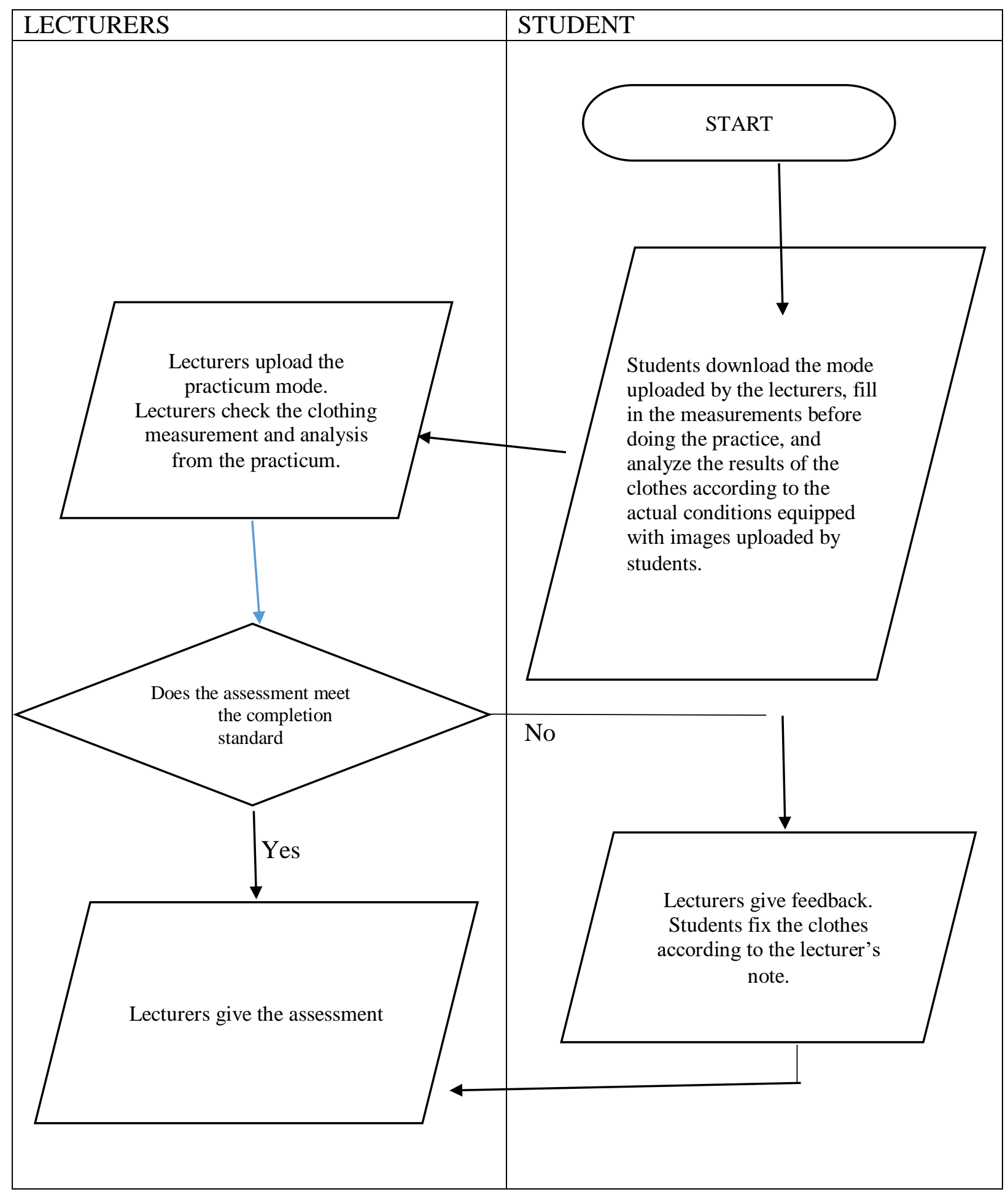

Figure 1. Assessment Results Flowchart for Practicum of Clothes Making

Based on the above chart, an analysis is required to complete the assessment in the practicum of clothes making. Figure 2 displays the required assessment analysis procedure. 
Result

Procedure

result of the

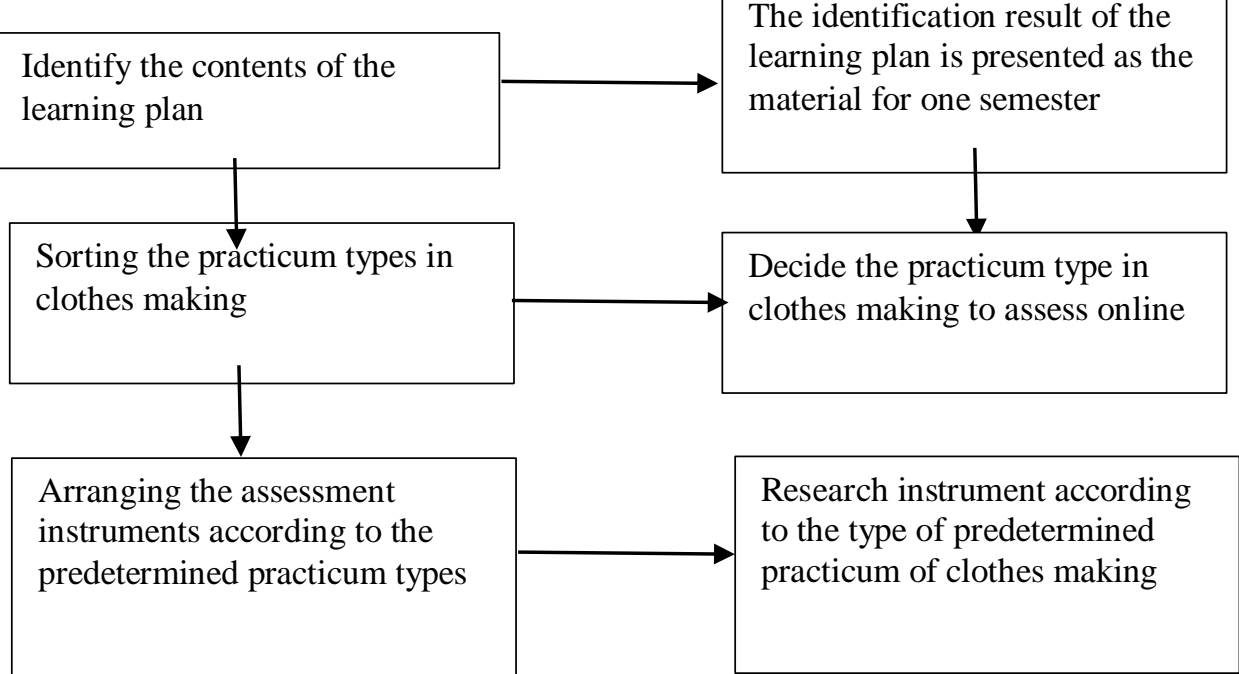

Figure 2. Analysis Procedure in Assessment Requirements for Practicum in Clothes Making

The first step in the identification of clothes making learning plan consisted of 16 meetings, including midterm and final term. The second step was sorting the practicum of clothes making. The sorting resulted in three types of practicum. They were: 1) skirt making practicum, 2) blouse making practicum, 3) gown making practicum, and 4)Skirt making practicum. The third step was to arrange the assessment instruments in the practicum of clothes making[4].

Arranging the instruments in the assessment involves skirt, blouse, and gown making. The component of each evaluation was: completeness component, completeness achievement component, and fitting component. The implementation of each element in the preparation of questions is illustrated in the questions. The online evaluation will include yes and no answers. Components the completion of: 1 .Products blouse has been completed and attached all parts of blouse, components these the completion of: 1.collar: forms collar appropriate to a picture mode, a lapel on a line of the neck just in accordance picture mode, technique sewing collar right, stitches collar flattened, big or small not, stitches collar no thread breaking up in the center collar; the 2 arms: forms arms appropriate to a picture mode, a the arm to circle line arms right on the line shoulder outermost, the difference size circle line arms that had already been prepared with the initial size no more than $5 \mathrm{~cm}$, technique sewing right, the completion of arms below in accordance . ; 3 opening of ritsruiting japan: a ritsruiting fitting in place , position ritsruiting closed, invisible teeth ritsruitingnya , the fall of ritsruiting which has been installed not wavy,
From the right side and left ritsruiting no material interested, the head around ritsruiting invisible tiras ritsruiting; ritsruiting opening a jacket: ritsruiting fitting in place, ritsruiting closed position, the edge ritruiting right left symmetrical, the fall of ritsruiting installed not wavy, from the right side and left ritsruiting no material interested, the ritsruitjaket right around the opening of a regular; ritsruiting: ritsruiting fitting in place, ritsruiting closed position, invisible ritsruitingnya teeth, the fall of ritsruiting installed not wavy, from the right side and left ritsruiting no material interested, the head; ritsruiting not visible from the outside

Opening studs: domicile of the buttons of fitting in the middle of the face of, the position of a buttonhole with studs attached right, the installation of a button right, sewing technique when buttons, closed position the right and left with a pile up the same length / according pictures, mode engineering concentrates on the tongue studs right; inlaid lines form inlaid lines in accordance with a picture, mode a notch inlaid lines exactly according to a picture, mode sew inlaid lines right, technique inlaid lines interesting, outlook stitches inlaid lines neat; finishing braus: resolution of the edge of using a technique, down the right the settlement of a button, the right of using a technique the right sewing, through a process of pressing at every step, carry out the process of triming, neat and interesting. Outlook A component fittings: the accuracy of the size of the final result braus: size so, waistlines the size of a long sleeveless, measure of length blous, size The completion of the edge, arms wide the size of wide The completion of the edge. Below is the table on the instruments and scoring. 
Table 1. Design Analysis of Blouse Making Practicum for System Pakar

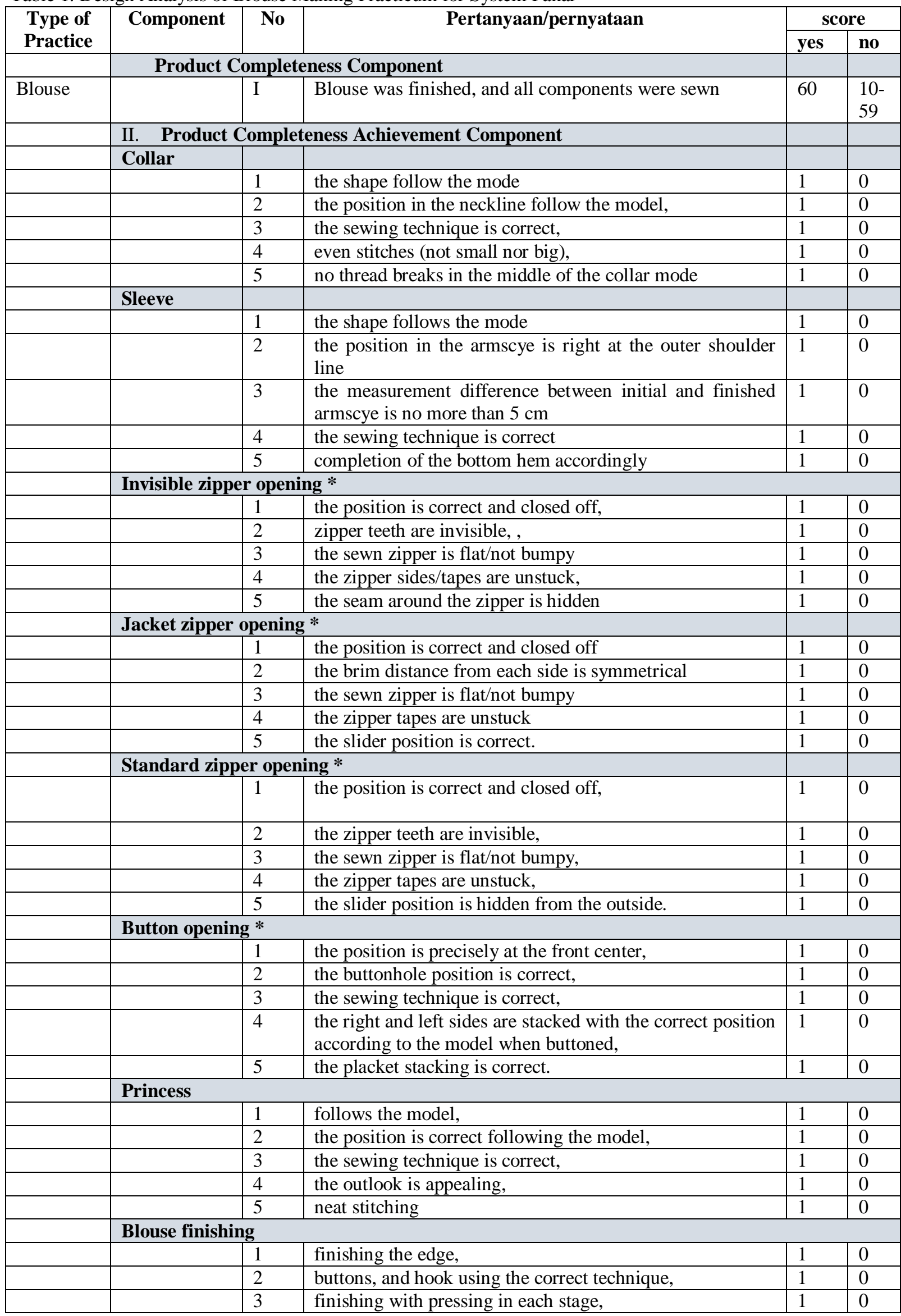




\begin{tabular}{|l|l|l|l|l|l|}
\hline & 4 & trimming, & 1 & 0 \\
\hline & 5 & the outlook is neat and appealing. & 1 & 0 \\
\hline & \multicolumn{3}{|c|}{ Fitting Component: Accuracy in the finishing } & 1 & 0 \\
\hline & 1 & the finished measurement of waistline, & 1 & 0 \\
\hline & 2 & sleeve length, & 1 & 0 \\
\hline & 3 & blouse length, & 1 & 0 \\
\hline & & 4 & sleeve hem width, & 1 & 0 \\
\hline
\end{tabular}

Table 2. Design Analysis of Skirt Making Practicum for System Pakar

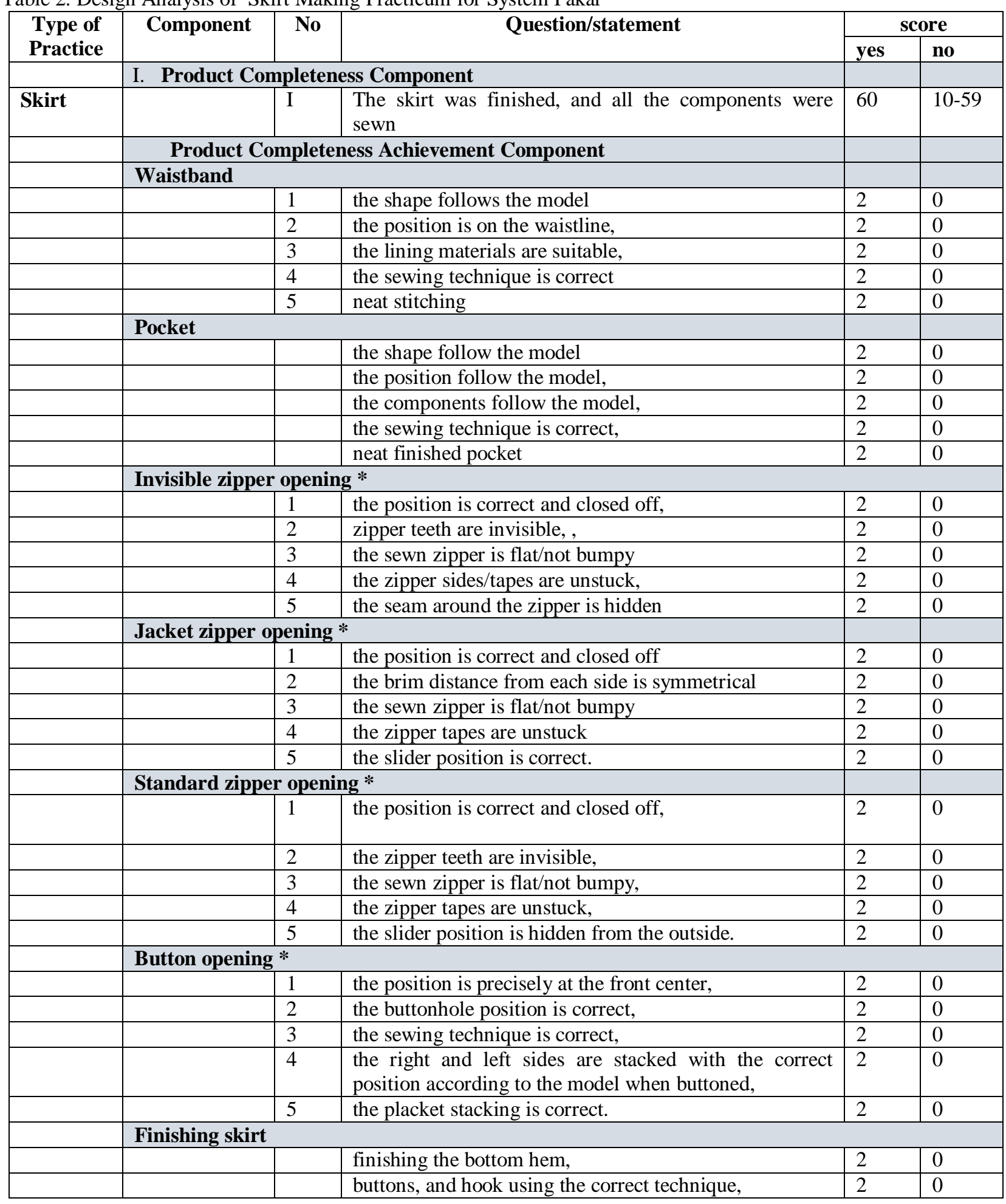




\begin{tabular}{|l|l|l|l|l|l|}
\hline & & finishing with pressing in each stage, & 2 & 0 \\
\hline & & trimming,. & 2 & 0 \\
\hline & \multicolumn{4}{|c|}{ the outlook is neat and appealing } & 2 \\
\hline \\
\hline
\end{tabular}

Table 3. Design Analysis of Gown Making Practicum for System Pakar

\begin{tabular}{|c|c|c|c|c|c|}
\hline \multirow{2}{*}{$\begin{array}{c}\text { Type of } \\
\text { Practice }\end{array}$} & \multirow[t]{2}{*}{ Component } & \multirow[t]{2}{*}{ No } & \multirow[t]{2}{*}{ Question/Statement } & \multicolumn{2}{|c|}{ score } \\
\hline & & & & \multirow[t]{2}{*}{ yes } & \multirow[t]{2}{*}{ no } \\
\hline & I. $\quad$ Product $\mathrm{Cc}$ & iplete & ess Component & & \\
\hline \multirow[t]{40}{*}{ Gown } & & I & The gown was finished, and all components were sewn & 70 & $10-69$ \\
\hline & II. & duct & mpleteness Achievement Component: & & \\
\hline & Collar & & & & \\
\hline & & 1 & the shape follow the mode & 1 & 0 \\
\hline & & 2 & the position in the neckline follow the model, & 1 & 0 \\
\hline & & 3 & the sewing technique is correct, & 1 & 0 \\
\hline & & 4 & even stitches (not small nor big), & 1 & 0 \\
\hline & & 5 & no thread breaks in the middle of the collar mode & 1 & 0 \\
\hline & Sleeve & & & & \\
\hline & & 1 & the shape follows the mode & 1 & 0 \\
\hline & & 2 & $\begin{array}{l}\text { the position in the armscye is right at the outer shoulder } \\
\text { line }\end{array}$ & 1 & 0 \\
\hline & & 3 & $\begin{array}{l}\text { the measurement difference between initial and finished } \\
\text { armscye is no more than } 5 \mathrm{~cm}\end{array}$ & 1 & 0 \\
\hline & & 4 & the sewing technique is correct & 1 & 0 \\
\hline & & 5 & completion of the bottom hem accordingly & 1 & 0 \\
\hline & Invisible zippe & open & & & \\
\hline & & 1 & the position is correct and closed off, & 1 & 0 \\
\hline & & 2 & zipper teeth are invisible, & 1 & 0 \\
\hline & & 3 & the sewn zipper is flat/not bumpy & 1 & 0 \\
\hline & & 4 & the zipper sides/tapes are unstuck, & 1 & 0 \\
\hline & & 5 & the seam around the zipper is hidden & 1 & 0 \\
\hline & Jacket zipper & penin & & & \\
\hline & & 1 & the position is correct and closed off & 1 & 0 \\
\hline & & 2 & the brim distance from each side is symmetrical & 1 & 0 \\
\hline & & 3 & the sewn zipper is flat/not bumpy & 1 & 0 \\
\hline & & 4 & the zipper tapes are unstuck & 1 & 0 \\
\hline & & 5 & the slider position is correct. & 1 & 0 \\
\hline & Standard zipp & open & $\lg *$ & & \\
\hline & & 1 & the position is correct and closed off, & 1 & 0 \\
\hline & & 2 & the zipper teeth are invisible, & 1 & 0 \\
\hline & & 3 & the sewn zipper is flat/not bumpy, & 1 & 0 \\
\hline & & 4 & the zipper tapes are unstuck, & 1 & 0 \\
\hline & & 5 & the slider position is hidden from the outside. & 1 & 0 \\
\hline & Princess & & & & \\
\hline & & 1 & follows the model, & 1 & 0 \\
\hline & & 2 & the position is correct following the model, & 1 & 0 \\
\hline & & 3 & the sewing technique is correct, & 1 & 0 \\
\hline & & 4 & the outlook is appealing, & 1 & 0 \\
\hline & & 5 & neat stitching & 1 & 0 \\
\hline & Gawn finishin & & & & \\
\hline & & 1 & finishing the edge, & 1 & 0 \\
\hline
\end{tabular}




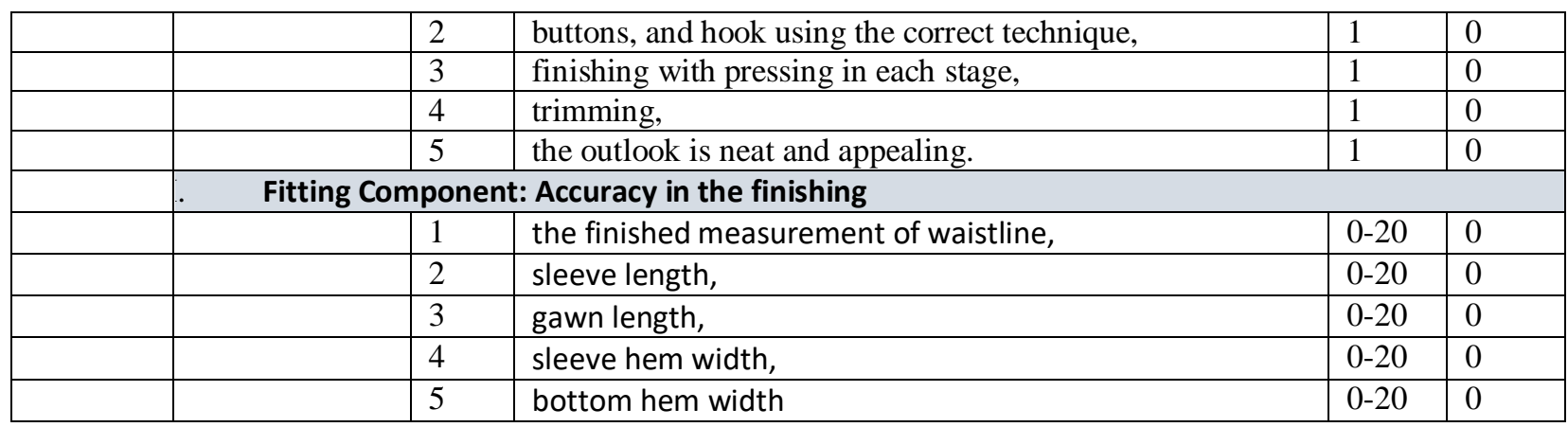

Table 4. Design Analysis of of Shirt Making Practicum for System Pakar

\begin{tabular}{|c|c|c|c|c|c|}
\hline \multirow{2}{*}{$\begin{array}{c}\text { Type of } \\
\text { Practice }\end{array}$} & \multirow[t]{2}{*}{ Component } & \multirow[t]{2}{*}{ No } & \multirow[t]{2}{*}{ Question/Statement } & \multicolumn{2}{|c|}{ score } \\
\hline & & & & \multirow[t]{2}{*}{ yes } & \multirow[t]{2}{*}{ no } \\
\hline & Product Com & oleten & Component & & \\
\hline \multirow[t]{38}{*}{ Shirt } & & I & The shirt was finished, and all components were sewn & 60 & $10-59$ \\
\hline & I. & apaiar & roduk & & \\
\hline & Collar & & & & \\
\hline & & 1 & the shape follow the mode & 1 & 0 \\
\hline & & 2 & the position in the neckline follow the model, & 1 & 0 \\
\hline & & 3 & the sewing technique is correct, & 1 & 0 \\
\hline & & 4 & even stitches (not small nor big), & 1 & 0 \\
\hline & & 5 & no thread breaks in the middle of the collar mode & 1 & 0 \\
\hline & Sleeve & & & & \\
\hline & & 1 & the shape follows the mode & 1 & 0 \\
\hline & & 2 & $\begin{array}{l}\text { the position in the armscye is right at the outer shoulder } \\
\text { line }\end{array}$ & 1 & 0 \\
\hline & & 3 & $\begin{array}{l}\text { the measurement difference between initial and finished } \\
\text { armscye is no more than } 5 \mathrm{~cm}\end{array}$ & 1 & 0 \\
\hline & & 4 & the sewing technique is correct & 1 & 0 \\
\hline & & 5 & completion of the bottom hem accordingly & 1 & 0 \\
\hline & Button openin & & & & \\
\hline & & 1 & the position is precisely at the front center, & 1 & 0 \\
\hline & & 2 & the buttonhole position is correct, & 1 & 0 \\
\hline & & 3 & the sewing technique is correct, & 1 & 0 \\
\hline & & 4 & $\begin{array}{l}\text { the right and left sides are stacked with the correct position } \\
\text { according to the model when buttoned, }\end{array}$ & 1 & 0 \\
\hline & & 5 & the placket stacking is correct. & 1 & 0 \\
\hline & Pocket & & & & \\
\hline & & & the shape follow the model & & \\
\hline & & & the position follow the model, & & \\
\hline & & & the components follow the model, & & \\
\hline & & & the sewing technique is correct, & & \\
\hline & & & neat finished pocket & & \\
\hline & Cuff & & & & \\
\hline & & & left and right cuffs are in the correct position, & 1 & 0 \\
\hline & & & sewing cuff slit technique is correct, button sewing & 1 & 0 \\
\hline & & & technique is correct, & 1 & 0 \\
\hline & & & $\begin{array}{l}\text { left and right sides are stacked in the same length and } \\
\text { direction when the cuff is buttoned, }\end{array}$ & 1 & 0 \\
\hline & & & cuff width measurement is accurate. & 1 & 0 \\
\hline & Finishing Shi & & & & \\
\hline & & & finishing the edge, & 1 & 0 \\
\hline & & & buttons, and hook using the correct technique, & 1 & 0 \\
\hline & & & finishing with pressing in each stage, & 1 & 0 \\
\hline & & & trimming, & 1 & 0 \\
\hline & & & the outlook is neat and appealing. & 1 & 0 \\
\hline
\end{tabular}




\begin{tabular}{|l|l|l|l|l|l|}
\hline & \multicolumn{5}{|c|}{ Fitting Component: Accuracy in the finishing } \\
\hline & & the finished measurement of waistline, & $0-20$ & 0 \\
\hline & & sleeve length, & $0-20$ & 0 \\
\hline & & gawn length, & $0-20$ & 0 \\
\hline & & sleeve hem width, & $0-15$ & 0 \\
\hline & & bottom hem width & $0-15$ & 0 \\
\hline
\end{tabular}

This requirement analysis is the initial step in designing the assessment. The assessment is designed to find the level of understanding after learning a specific competency [4]. Requirement analysis of practicum assessment using exspert is a derivative from practicum competency. This statement is in accordance with the research of I Gede Sudhirta that argued that several vital aspects in fashion practicum assessment were (1) design analysis, (2) drafting and pattern drafting performance, (3) pattern placement and material cutting performance, (4) sewing/combining clothing parts performance, and (5) clothing finishing, displaying, and packaging performance [4].

\section{METHOD}

This research was research and development. The method was chosen to create particular product and test the product's effectivity [5], be it new product or existing product [6]. Assessment design requirement analysis was conducted through procedural stages [5]. This research used the ADDIE (Analysis-DesignDevelopment-Implementation-Evaluation) method. The ADDIE model is a research and development model that provides an organized process for learning, face-toface or online learning. Besides, the ADDIE model gives a chance to the learning design developers to cooperate with exspert systems in content, media, and learning design to produce good quality products [7].The complete research procedure, including analysis, design, development, implementation, evaluation, was conducted at the State University of Malang. The model in this research was a procedural model that outlines the stages to create a product. The product of this research was a requirement analysis in practicum assessment design using exspert.

The data collecting instruments followed the research's purpose. There were two sheets of instruments; the first was for validation and contained questionnaires, suggestions, and comments. A questionnaire is several written questions to obtain information [9]. The content of the questionnaire involved an assessment form for the exspert systems. The instrument on product feasibility and online learning material used the Likert scale with alternative answers of: excellent, good, poor, and very poor. To obtain the quantitative data, the responses above were scored, such as excellent $=4$, $\operatorname{good}=3$, poor $=2$, and very poor $=1$.

\section{RESULTS AND DISCUSSION}

The assessment instrument design of clothes making practicum was developed through the stage of requirement analysis from literature review and study in the competency of the practicum course by involving the related lecturer. This study resulted in some aspects that needed to assess in clothes making practicum, such as blouse making practicum assessment design, skirt making practicum assessment design, gown making practicum assessment design, and shirt making practicum assessment design. Next was to arrange the instrument design. Instrument design for each practicum covered three main points: product completeness component, completeness achievement component, and fitting. The development of requirement analysis in clothes making practicum was performed by judges or exspert system validity tests and revision based on the specialist check. After, this research conducted the trial are easy to understand and answer and unambiguous or have double perceptions. The table below presents the trial results.

\section{REFERENCES}

[1] I Gede Sudhirta. 2014. Pengembangan Instrumen Asesmen Kuliah Praktik Tata Busana Pada program Studi pendidikan Tata Busana. https://Ejou rnal.undiksha. ac.id/index.php/JPI/ article/view/2915).

[2] Ramadhani, P., Wardhani, D.K., Nugroho, E.S. Sistem Pakar Diagnosa Infeksi Penyakit Tropis Berbasis Web. Jurnal Teknik Informatika Vol. 1 September 2012

[3] Grainner (1998), Penyederhanaan Bayes . Jakarta: Luhur.

[4] Irianti Agus Hery Supadmi, dkk .2019. Pengembangan Model Evaluasi Hasil Belajar Praktikum Pembuatan Busana Menggunakan Sistem Pakar Di Prodi Tata Busana UM Malang:UM

[5] Sugiyono. 2012. Metode Penelitian Kombinasi (Bandung: Alfabeta)

[6] Syaodih Sukmadinata 2009. Pengembangan Mata Pelajaran Teori dan Praktek. Bandung.PT Remaja Rosdakarya Offset.

[7] Chaeruman, 2008. Rencana Pembelajaran yang Mengintergrasikan Teknologi Informasi dan Komunikasi. Pusat Teknologi Informasi dan Komunikasi Pendidikan Departemen Nasional. 